\section{SCIDOC \\ Publishers}

Infer, Interpret \& Inspire Science

\title{
Effects of Propolis, Royal Jelly, Bee Pollen and Ronozyme Supplementation in Diets of Japanese Quails (Coturnix Coturnix Japonica) on Yolk Lipid Peroxidation
}

Research Article

Yilmaz $\mathrm{S}^{1 *}$, Tatli Seven $\mathrm{P}^{2}$, Kaya $\mathrm{E}^{1}$

${ }^{1}$ Department of Biochemistry, Faculty of Veterinary Medicine, University of Firat, Elazig, Turkey.

${ }^{2}$ Department of Animal Nutrition and Nutritional Diseases, Faculty of Veterinary Medicine, University of Firat, Elazig-Turkey.

\section{Abstract}

This study discovers the possible effect propolis, royal jelly, bee pollen and Ronozyme supplementation in diets that can be beneficial for Japanese quails (Coturnix coturnix japonica). Total one hundred and sixty Japanese quails at 43 days of age were used and divided randomly into 4 replicate groups each containing 32 animals. The experimental groups as follows: control group was feed a basal diet, royal jelly group was added to the water with $500 \mathrm{mg} / \mathrm{kg}$ diet, propolis group was feed orally on a basal diet supplemented with $4 \mathrm{~g} / \mathrm{kg}$ diet, bee pollen group was feed orally on a basal diet supplemented with $1 \mathrm{~g} / \mathrm{kg}$ diet, Ronozyme group was feed orally a basal diet supplemented with $1 \mathrm{~g} / \mathrm{kg}$ diet for 74 days. Malondialdehyde (MDA) levels of the yolk were found highest in the control, royal jelly and Ronozyme groups as compared with bee pollen and propolis groups $(\mathrm{p}<0.05)$. MDA levels was significantly improved in the bee pollen and propolis groups as compared with royal jelly and Ronozyme groups $(\mathrm{p}<0.05)$. In conclusion, this experiment demonstrated that quails supplemented with propolis and bee pollen could produce egg rich. This study will help the researcher to uncover the critical areas of egg quality that many researchers were not able to explore. Thus a new theory on these compounds may be arrived at.

Keywords: Malondialdehyde; Yolk; Quail; Propolis; Royal Jelly; Bee Pollen; Ronozyme.

\section{Introduction}

Eggs have a high nutritional value and contain a variety of necessary components for the maintenance and the normal function of the human organism [1].

Lipid oxidation by free radicals is one of the primary mechanisms of quality deterioration in eggs. It is initiated in the highly unsaturated fatty acid fraction of membrane phospholipids, leading to the production of hydroperoxides, which are susceptible to further oxidation or decomposition to secondary reaction products such as short-chain aldehydes, ketones and other oxygenated compounds that may adversely affect lipids, pigments, proteins, carbohydrates, vitamins and the overall quality by causing loss of flavour, colour and nutritive value and limiting shelf-life [2]. Malondialdehyde (MDA) is one of the major lipid peroxidation products. This aldehyde is formed during lipid peroxidation of fatty acids with three or more double bonds [3].
Studies to improve oxidative stability of eggs and meat via dietary antioxidant enrichments [2, 4] reveal an inverse relationship between levels of dietary antioxidant and MDA contents in yolk, meat, a lipid peroxidation indicator in the poultry products. In the past, synthetic antioxidants were used with the intention of preventing lipid oxidation by scavenging chain-carrying peroxyl radicals or diminishing the formation of lipid radicals [5]. In the last decade, there has been a strong tendency towards using organic antioxidants from natural sources for the protection of animal health and their products against oxidation [6]. As a result, considerable interest has arisen in the use of natural supplements that could serve as alternatives to synthetic supplements on purpose to improve egg quality [7-9].

Royal jelly also contains vitamins, minerals, enzymes and antibiotic components. Royal jelly has been determined to exhibit a variety of pharmacological activities including antitumor,

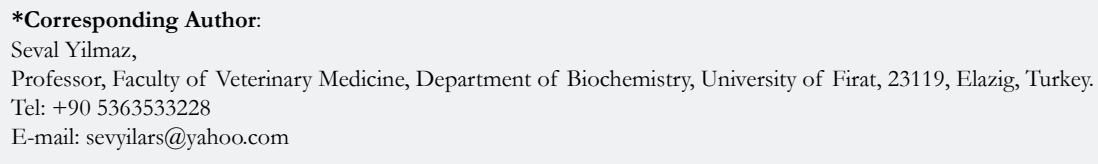

Citation: Y1lmaz S, Tatli Seven P, Kaya E (2017) Effects of Propolis, Royal Jelly, Bee Pollen and Ronozyme Supplementation in Diets of Japanese Quails (Coturnix Coturnix Japonica) on Yolk Lipid Peroxidation. Int J Vet Health Sci Res. 5(5), 183-189. doi: http://dx.doi.org/10.19070/2332-2748-1700037

Copyright: Y1lmaz S $\mathbf{S}^{\circ}$ 2017. This is an open-access article distributed under the terms of the Creative Commons Attribution License, which permits unrestricted use, distri bution and reproduction in any medium, provided the original author and source are credited. 
antimicrobial, antioxidant activity, vasodilative and hypotensive activities, as well as growth stimulating and infection preventing, antihypercholesterolemic and anti-inflammatory activities.

Propolis (bee glue) is a natural resinous hive product collected by bees from plants, particularly from flowers and leaf buds. Propolis generally contains $30 \%$ beeswax, $5 \%$ pollen, $50-55 \%$ resinous substances and 15\% essential oils [10]. Propolis has shown diverse biological activities: antimicrobial activity against different bacteria and yeast, parasites; antioxidant, cytotoxic and potential antitumor activity, antipsoriatic, anti-inflammatory and analgesic activities, anti-obesity and hepatoprotective effects [11, $12]$.

Bee pollen is a powder-like material produced by flowering plants pollen, mixed with nectar and bee secretions and gathered by the honey bees. Pollen is called the only perfectly complete food and the main biological components of bee pollen are the phenolic acid derivatives and polyphenolic compounds, mostly flavonoid glycosides. The flavonoids are so called secondary plant compounds which have different important physiological and pharmacological activities. They possess diverse biological properties such as antioxidant, anti aging, anticarcinogenic, antiinflammatory, antiatherosclerosis, cardioprotective and improve the endothelial function $[13,14]$.

Incorporating Ronozyme ${ }^{\circledR}$ ProAct in diets helps reduce feed costs without compromising performance. Protein is one of the most expensive components of any livestock diet, but is essential for growth. The challenge, therefore, is to use protein as efficiently as possible so as to reduce feed costs without compromising animal health. Proteases are enzymes that break down protein molecules into the amino acids and peptides needed by animals. Specifically developed for inclusion in animal diets, Ronozyme significantly increases the digestibility of protein. It complements naturally occurring proteases in feed, and considerably increases amino acid and peptide supply so as to enhance animal performance. It improves the digestibility of a wide range of protein sources and cereals, allowing savings in diet costs [15].

This experiment was conducted to investigate the effects of royal jelly, propolis, bee pollen and Ronozyme supplementation in diets of Japanese quails (Coturnix coturnix japonica) on contents of MDA in yolk.

\section{Materials and Methods}

Total one hundred and sixty Japanese quailsat aged of 43 days were used and divided into 4 replicate groups each containing 32 animals. All of birds were placed into cages with an internal dimension of $40 \times 32 \mathrm{~cm}$. The experimental groups as follows: Group 1 (control) was feed a basal diet. Group 2 was added to the water with $500 \mathrm{mg} / \mathrm{kg}$ dietroyaljelly [16]. Group 3 was feed a basal diet supplemented with $4 \mathrm{~g}$ propolis $/ \mathrm{kg}$ diet. Group 4 was feed a basal diet supplemented with $1 \mathrm{~g}$ bee pollen/ $\mathrm{kg}$ diet [17]. Group 5 was feed a basal diet supplemented with $1 \mathrm{~g}$ Ronozyme $/ \mathrm{kg}$ diet. The experiment was continued during 74 days.

The ingredients and chemical composition of the diets are presented in Table 1. Chemical composition of feed ingredients

Table 1. Ingredient Composition and Chemical Composition of the Experimental Diets $(\mathrm{g} / \mathrm{kg})$.

\begin{tabular}{|c|c|c|}
\hline Ingredients & Starter & Finisher \\
\hline Maize & 539.8 & 621.3 \\
\hline Soybean meal & 266.3 & - \\
\hline Full fat soybean & 124.8 & 276.5 \\
\hline Poultry meal & 25 & 60 \\
\hline Soybean oil & 9.4 & 14.3 \\
\hline Limestone & 11.9 & 2.9 \\
\hline Bone meal & - & 16.5 \\
\hline Dicalcium phosphate & 11.9 & - \\
\hline Salt & 3 & 2.1 \\
\hline DL-methionin & 2.8 & 1.3 \\
\hline Vitamin-mineral premix ${ }^{a}$ & 3.5 & 3.5 \\
\hline Lysine & 1.6 & 1.6 \\
\hline \multicolumn{3}{|l|}{ Calculated content } \\
\hline $\mathrm{ME}, \mathrm{kcal} / \mathrm{kg}^{\mathrm{c}}$ & 3300 & 3030 \\
\hline Dry matter, $\%{ }^{\mathrm{b}}$ & 89.4 & 90.50 \\
\hline Crude protein $(\mathrm{CP}), \%^{\mathrm{b}}$ & 23.62 & 19.25 \\
\hline Ether extract, $\%{ }^{\mathrm{b}}$ & 6.1 & 8.9 \\
\hline Ash, $\%{ }^{b}$ & 5.1 & 4.3 \\
\hline Crude cellulose, $\%{ }^{\mathrm{b}}$ & 5.0 & 5.6 \\
\hline Calcium $^{c}$ & 10 & 10.2 \\
\hline Total phosphorus ${ }^{c}$ & 5.5 & 5.6 \\
\hline
\end{tabular}

a Vitamin-mineral premix provided per kilogram of diet: retinol, $4.5 \mathrm{mg}$; cholecalciferol $0.125 \mathrm{mg}$; Alpha-tocopherol, $100 \mathrm{mg}$; menadione, 4 mg; thiamine, 3 mg; riboflavin, 8 mg; niacin, 60 mg; pyridoxine, 5 mg; Ca-Dpantothenate, 18 mg; folic acid, 2 mg; D-biotin, 0.20 mg; Mn, 100 mg; Zn, 80 mg; Fe, 80 mg; Cu, 8 mg; Co, $8 \mathrm{mg}$; Se, 0.3 mg; Iodine, $1 \mathrm{mg}$, Mo, $1 \mathrm{mg}$; choline chloride, $500 \mathrm{mg}$.

${ }^{\mathrm{b}}$ Analysed AOAC(1995). ${ }^{\mathrm{c}}$ Based on NRC (1994) feed composition tables. 
(dry matter, crude protein, aether extract and ash) as dried samples was analysed using AOAC [18] procedures. Corn and soybean meal-based feeds were formulated to be isonitrogenic and isoenergic according to the NRC [19] recommendation. All groups were kept under the same environmental conditions. Feed and water were given ad libitum.

Royal jelly and bee pollen were obtained from a commercial firm in Turkey. Royal jelly dissolved in distilled water, and kept frozen at $-20^{\circ} \mathrm{C}$ until used. Chemical composition of royal jelly was assessed by gas chromatography-mass spectrometry (GC-MS, Agilent GC 6890 gas chromatograph) analyses (Table 2). Ronozyme was provided DSM Nutritional Products Inc. Pollen and Ronozyme were homogeneously mixed carefully to the basal diet. Propolis samples were collected from the Karabük Province (Middle Black Sea). Afterwards, propolis samples were kept desiccated in the dark until the processing. The samples were extracted for a week with $100 \mathrm{ml}$ of $70 \%$ ethanol at room temperature to obtain the extract. After filtration, the extract was evaporated using a vacuum evaporator at $45^{\circ} \mathrm{C}$ and then used in the experiment. GC-MS was carried out to detect main components of propolis by the gas chromatograph coupled to the Agilent MSD 5973 mass detector under electron impact ionization. The main compounds of the propolis sample were identified and are listed in Table 3.

At the end of the experiment, 42 eggs per each group (2 eggs from each replicate) were randomly chosen to determine the MDA concentration of yolk. The yolk samples were mixed with
$1.15 \% \mathrm{KCl}$ at the 1:10 ratio (weight/volume) then homogenized onto fragmented ice. The homogenates were centrifuged at $18.000 \mathrm{xg}\left(+4^{\circ} \mathrm{C}\right)$ for $30 \mathrm{~min}$ to determine MDA concentrations. The MDA concentration as a marker of lipid peroxidation were determined according to the method of Placer et al., [20] based on the reaction with thiobarbituric acid. The concentrations of reagent $(10 \%, \mathrm{w} / \mathrm{v}$ trichloroacetic acid and $0.168 \%, \mathrm{w} / \mathrm{v}$ TBA) were mixed in a glass tube. The solution was warmed for $20 \mathrm{~min}$. The precipitate was removed by centrifugation at $4.000 \mathrm{~g}$ for 10 min. The formed MDA created a pink complex with thiobarbituric acid and the absorbance was read at $532 \mathrm{~nm}$. The MDA content was expressed as $\mathrm{nmol} / \mathrm{ml}$.

\section{Statistical Analysis}

The results are expressed as mean \pm standard error (S.E.). Statistical significance between the different groups was determined by using one way analysis of variance (ANOVA) in the SPSS 21 software package. Post hoc test was performed for betweengroup comparisons by using the Tukey multiple comparison test. All data are expressed as mean \pm S.E. The level of significance was set at $\mathrm{p}<0.05$.

\section{Results}

All eggs were collected on end of experiment and the yolk was evaluated MDA levels. MDA levels of the yolk were found highest

Table 2. Chemical Composition of Royal Jelly assessed by GC-MS.

\begin{tabular}{|c|c|c|}
\hline RT (min) & Contents & TIC (\%) \\
\hline \multicolumn{3}{|c|}{ Flavonoids } \\
\hline 36.337 & Chrysin & 0.847 \\
\hline 33.502 & Pinocembrin & 1.842 \\
\hline 35.114 & Tectochrysin & 0.382 \\
\hline 32.176 & Pinostrobin chalcone & 0.735 \\
\hline \multicolumn{3}{|c|}{ Alcohol } \\
\hline 2.222 & Furfuryl alcohol & 0.279 \\
\hline \multicolumn{3}{|c|}{ Organic compounds } \\
\hline 8.871 & Hydroxymethylfurfurole & 0.656 \\
\hline \multicolumn{3}{|c|}{ Fatty acids } \\
\hline 16.924 & 3-Hydroxydecanoic acid & 1.494 \\
\hline 19.463 & 10-Hydroxydecanoic acid & 19.815 \\
\hline 32.398 & Oleic acid amide & 0.692 \\
\hline 14.924 & Octanoic acid, 8-hydroxy-(CAS) & 3.226 \\
\hline \multicolumn{3}{|c|}{ Other } \\
\hline 2.896 & 2-Penten-4-olide & 4.110 \\
\hline 5.751 & 4,5-Diamino-2-hydroxypyrimidine & 0.648 \\
\hline 7.150 & 3,5-Dihydroxy-6-mehyl-2,3-dihydro-4H-pyran-4-one & 1.409 \\
\hline 3.891 & Glutaconicanhydride & 1.024 \\
\hline 37.213 & 9-(4-Aminophenyl)acridine & 0.489 \\
\hline 42.011 & Benzeneethanamine, N-[(4-nitrophenyl)methylene] & 0.375 \\
\hline 44.099 & Ostreasterol & 1.924 \\
\hline 41.555 & 3-Hydroxydiphenylamine & 0.336 \\
\hline 22.868 & 3-(4-Nitrophenyl)propiolic acid trans-1,1-dichloro-2,3-diethylcyclopane & 1.336 \\
\hline
\end{tabular}

RT: Retention time. TIC: The ion current generated depends on the characteristics of the compound concerned and is not a true quantitation. 
Table 3. Chemical Composition of Propolis as Assessed by GC-MS.

\begin{tabular}{|c|c|c|}
\hline $\mathrm{RT}(\mathrm{m})$ & Contents & TIC $(\%)$ \\
\hline \multicolumn{3}{|c|}{ Aromatic Alcohols } \\
\hline 4.787 & Benzyl alcohol & 0.279 \\
\hline 11.334 & 2-Methoxy-4-vinylphenol & 0.55 \\
\hline 11.047 & Cinnamic alcohol Aromatic Acids & 0.455 \\
\hline 8.309 & Benzoic acid & 1.123 \\
\hline 24.097 & İsoferulic acid & 0.908 \\
\hline 28.866 & p-coumaric acid & 0.404 \\
\hline 14.418 & Cinnamic acid & 1.043 \\
\hline \multicolumn{3}{|c|}{ Esters } \\
\hline 24.433 & Dimethyl caffeic acid & 1.798 \\
\hline 32.845 & Cinnamyl cinnamate & 1.863 \\
\hline \multicolumn{3}{|c|}{ Fatty acids } \\
\hline 26.121 & Palmitic acid & 0.418 \\
\hline 29.268 & Oleic acid & 1.959 \\
\hline 29.065 & Linoleic acid & 0.626 \\
\hline \multicolumn{3}{|c|}{ Flavanoids } \\
\hline 36.679 & Chrysin & 18.168 \\
\hline 33.714 & Pinosembrin & 16.828 \\
\hline 32.281 & Pinostrobin chalcone & 7.129 \\
\hline 37.381 & Galangin & 7.887 \\
\hline 35.214 & Tektochrysin & 9.503 \\
\hline 40.607 & Pectolinarigenin & 0.316 \\
\hline 37.555 & Sakuranetin & 1.055 \\
\hline \multicolumn{3}{|c|}{ Terpens } \\
\hline 34.117 & Abietic acid & 0.311 \\
\hline 19.479 & Alfa eudesmol & 0.557 \\
\hline 33.398 & Dehydroabietic acid & 0.678 \\
\hline 19.345 & Beta-selinenol & 0.728 \\
\hline \multicolumn{3}{|c|}{ Others } \\
\hline 9.222 & 4- vinylphenol & 0.438 \\
\hline 33.039 & 5-Methyl-1,3-benzendicarbocsilic acid & 2.478 \\
\hline 37.840 & İsomaturinin & 0.833 \\
\hline 38.316 & 3-phenyl pyrrolidine & 0.611 \\
\hline 39.099 & 3-ciyano-5,6-dimethoxy-2-methylthio-1-felnilindole & 0.464 \\
\hline 17.251 & Methyl-4-phenyl-3-bütenoat & 0.86 \\
\hline 29.660 & Pyridine,1-asetil-1,2,3,4-tetrahidro-5-(2-pyrrolidinil) & 0.998 \\
\hline 35.870 & Rheochrysidin & 0.573 \\
\hline 39.817 & Chrysophanic acid & 1.14 \\
\hline
\end{tabular}

RT: Retention time, minute

TIC: The ion current generated depends on the characteristics of the compound concerned and is not a true quantitation.

Figure 1. The Effect of royal jelly, propolis, bee pollen and ronazyme supplementation on yolk MDA level.

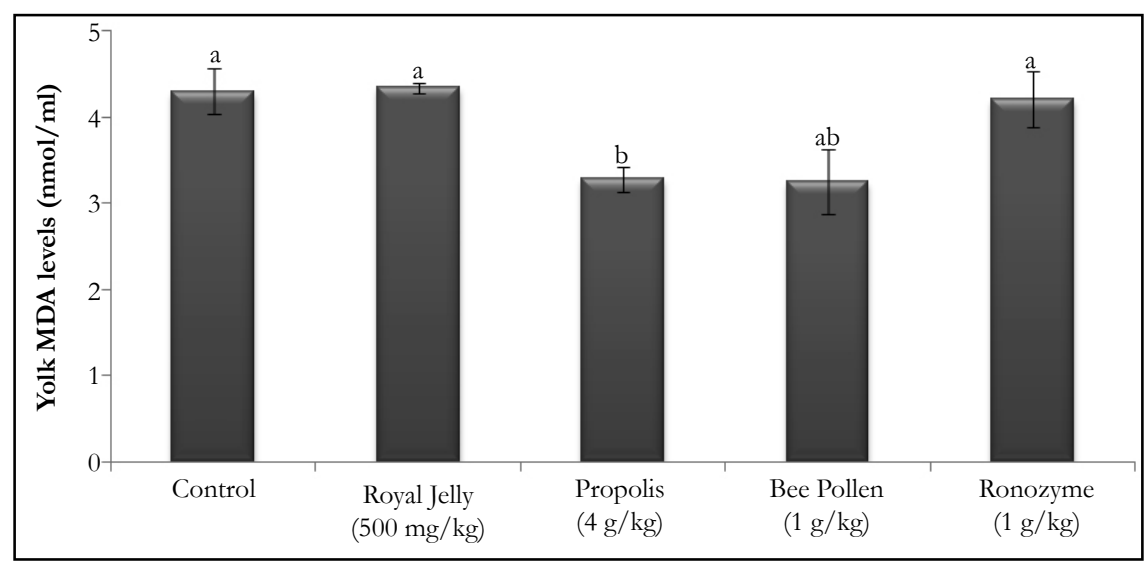


in the control, royal jelly and Ronozyme groups as compared with bee pollen and propolis groups $(\mathrm{p}<0.05)$. MDA levels of the yolk in bee pollen and propolis groups were significantly lower than those of other groups $(\mathrm{p}<0.05)$. MDA levels of yolk in bee pollen and propolis groups were found to be similar.

\section{Discussion}

The egg is the most complete food in nutritional point of view. Lipid oxidation is a process that has significant effect on the food industry because it can alter food quality (rancidity, flavor, odor, and color) and may lead to toxic end product accumulation. Lipid oxidation of foods is of great interest because it results in decreased nutritional value and sensory quality [21, 22]. The oxidative stability of shell eggs in storage has not generally been a major problem because they contain several naturally occurring compounds that protect the in-shell system from oxidation. Phosvitin, a yolk protein, and conalbumin, an albumen protein, have both been shown to exert antioxidant activity by inhibiting $\mathrm{Fe}^{2+}$ and $\mathrm{Cu}^{2+}$ catalysed reactions, whereas other yolk constituents including $\alpha$-tocopherol, xanthophylls and lecithin, have all been shown to be very effective in preventing oxidation of yolk lipids [5]. Although shell eggs are relatively stable against oxidation, processed eggs have been shown to be subject to lipid oxidation. Recently, the susceptibility of processed eggs to lipid oxidation has been of increased concern due to the production of 'modified' eggs that are highly unsaturated and may, therefore, be more prone to oxidation during storage or processing, particularly, at low $\mathrm{pH}$. As emerging egg technology produces more 'modified' eggs, there may be an increasing interest on the oxidative deterioration of marketed eggs $[8,23]$.

Several studies have reported the effects of dietary supplementation as a means of improving the oxidative stability of eggs. In a study, to investigate the effect of diet on lipid oxidation of shell eggs during refrigerated storage, 4 freshly collected eggs from each subgroup, totalling 16 eggs from each dietary treatment were used. Four eggs, each from a different subgroup of each dietary treatment, were directly analysed for yolk MDA content, while the others were stored at $+4^{\circ} \mathrm{C}$ to be analysed in sets of 4 eggs at 30,45 and $60 \mathrm{~d}$ of storage. The extent of lipid oxidation, as measured by MDA formation, differed between treatments but did not change with storage time. The concentrations of MDA found in yolks must have been due to consumption and subsequent deposition of MDA already formed in the diets or to in vivo production and deposition of MDA by the hens during digestion [8].

The extent of lipid oxidation is commonly determined by an assay based on reaction between 2-thiobarbituric acid (TBA) and MDA during heating at acidic $\mathrm{pH}$. Experienced investigators have cautioned that this assay may give misleading results due to the contribution of other compounds in addition to the TBA-MDA complex formed and, hence, the term 'thiobarbituric acid reactive substances' (TBARS) is frequently used [24]. TBA reactivity can be influenced by several factors including the formation of MDA as an artefact in the analysis during the assay itself and the occurrence of MDA in various bound forms [25]. The spectrophotometric method used in the present study substantially improves the reliability of the measurements because the applied third-order derivative spectral analysis of the TBA-MDA complex eliminates potential interference from other reactive compounds, whereas the sample preparation procedure inhibits lipid oxidation occurring in vitro during the assay itself.

Dietary inclusion of royal jelly and Ronozyme did not affect the yolk MDA concentration. Similarly, Yalçın et al., [26] found that yeast autolysate supplementation did not affect the MDA concentration of eggs. However, Zhang et al., [27] reported that dietary supplementation with $S$. cerevisiae improved the oxidative stability of broiler meat and suggested that this was due to some antioxidant factors present in $S$. cerevisiae shifting the oxidative fat or fatty acid profile in the meat.

Living organisms are able to adapt to oxidative stress by inducing the synthesis of antioxidant enzymes and damage removal/repair enzymes [28]. It was found that the MDA levels in yolk were significantly higher in the control group compared to the bee pollen and propolis groups. Ahmad et al., [29] reported a decrease in circulating triglycerides in the birds due to increased unsaturated fatty acids intake, which can reduce the availability of lipids for the formation of yolk. They also reported that unsaturated fatty acids could affect the circulating estradiol and suggested that the dietary unsaturated fatty acids could alter the hormonal metabolism of the birds. Galal et al., [30] reported that eggshell quality was significantly affected by propolis supplementation, whereas the percentage and thickness of eggshell were significantly increased in the egg produced from hens fed diet containing 100 and 150 mg propolis. Tatli Seven [31] reported that under heat stress condition propolis supplementation significantly increased egg shell thickness and egg shell weight in laying hens. This may be due to improved calcium digestibility and absorption resulting from the acid derivatives such as benzoic, 4-hydroxy-benzoic which are found in propolis.

Babaei et al., [32] indicated that the addition of $5000 \mathrm{mg} /$ $\mathrm{kg}$ propolis, $5000 \mathrm{mg} / \mathrm{kg}$ bee pollen could be beneficial in improving growth performance of quail chicks. This may be due to the antimicrobial and immunostimulant activity of honey bee products. It opens perspective uses of honey, bee pollen and propolis as a feed additive to improve poultry performance. A similar finding was reported that Alternanthera brasiliana and propolis extracts increased body weight gain from 14 to 21 days [33]. Increased dietary $5000 \mathrm{mg} / \mathrm{kg}$ propolis and $5000 \mathrm{mg} / \mathrm{kg}$ bee pollen supplementation and $2.20 \%$ aqueous honey tended to improve feed efficiency. In another study it was reported that addition of propolis powder at $0.5,1.0$ and $1.5 \mathrm{~g} / \mathrm{kg}$ diet increased the growth parameters of quail chicks [34]. Supplementation of propolis in broiler diets at a level of $500 \mathrm{mg} / \mathrm{kg}$ increased body weight gain by $20.00 \%$. This improvement of weight gain could be due to the high content of flavonoids in propolis diets and increased Feedintakes (FI) compared to control group [35]. Experimental work of some investigators showed that propolis supplementation to the ration of pullets improved FCR [36]. FI and FCR significantly decreased by increasing levels of bee pollen and propolis supplementation. When $400 \mathrm{mg} / \mathrm{kg}$ and $800 \mathrm{mg} /$ $\mathrm{kg}$ bee pollen extract were added in feed mixtures for feeding broiler chickens, was increased in experimental groups compared to control group [37].

Bee pollen is widely used as a natural supplement, as it contains most of the essential elements needed for growth and developments in human beings and animals [38-40]. Bee pollen contains significant amounts of flavonoids, carotenoids and phytosterols. Flavonoids 
are polyphenolic substances. Polyphenols have strong antioxidant capacity [41]. They are capable of scavenging free radical due to metal chelation properties [42, 43]. They analysed antioxidant properties of chesnut bee pollen before the treatment and determined that the chestnut bee pollen possessed many phenolic compounds, which are the factors of high antioxidant properties. It was reported that bee pollen supplementation decreases markers of oxidative stress, enhancing the antioxidant system of animals under stress [44]. Bee pollen might be suggested for useful properties in the prevention of disease in which free radicals ocur [45]. Besides, it has been reported that bee pollen has metal chelation properties that react with free radicals [42]. Their function is to hunt down free radicals and neutralize them. In so doing, they not only prevent free radicals from causing damage but also repair any damages [46]. They analysed antioxidant properties of chesnut bee pollen before the treatment and determined that the bee pollen possessed many phenolic compounds, which are the factors of high antioxidant properties. It was reported that bee pollen supplementation decreases markers of oxidative stress, enhancing the antioxidant system of animals under stress [44].

In the present study, increasing of yolk MDA level in the control group may be evidence of oxidative stress. The results of the current study showed that propolis and bee pollen supplementation to quails diet has improved much more than those of royal jelly and Ronozyme supplementation to lipid peroxidation. This may be due to more powerful antioxidant content of bee pollen and propolis than that of royal Jelly, Ronozyme and its antiimmune properties. Inclusion of bee propolis and/or pollen to diet decreased lipid oxidation and prolonged the shelf life of egg, in case of propolis and bee pollen having unsaturated fatty acid composition consumed by layers. This may be due to the antimicrobial and immunostimulant activity of honey bee products.

\section{Conclusion}

Propolis and bee pollen used as alternative to antioxidants had positive effects on lipid peroxidation. Therefore, propolis and bee pollen can be recommended as a egg promoter in quail production. They can be used as preventing lipid oxidation. It opens perspective uses of bee pollen and propolis as feed additive to improve poultry performance. In summary, the present study suggested that bee pollen and propolis supplementation to diet had potential protective activity on lipid peroxidation. Propolis and bee pollen can be used as an additive in the ration of poultry because of antioxidant capacity.

\section{References}

[1]. Huang Z, Leibovit H, Lee CM, Millar R (1990) Effect of dietary fish oil on omega-3 fatty acid levels in chicken eggs and thigh flesh. J Agri food chem. 38(3): 743-747.

[2]. Angelo AJS, Vercellotti J, Jacks T, Legendre M (1996) Lipid oxidation in foods. Crit Rev Food Sci Nutr. 36(3): 175-224.

[3]. Cherian G, Wolfe FW, Sim JS (1996) Feeding dietary oils with tocopherols: effects on internal qualities of eggs during storage. J Food Sci. 61(1): 15-18.

[4]. Sahin N, Akdemir F, Orhan C, Kucuk O, Hayirli A, et al., (2008) LycopeneEnriched quail egg as functional food for humans. Food Res Int. 41(3): 295300.

[5]. Cuppert SL (2001) The Use of Natural Antioxidants in Food Products of Animal Origin. Antioxidants in Food, 302 (Cambridge, Woodhead).

[6]. Wenk C (2003) Herbs and botanicals as feed additives in monogastric animals. Asian-Australas J Anim Sci. 16(2): 282-289.
[7]. Galobart J, Barroeta AC, Baucells MD, Codony R, Ternes W (2001) Effect of dietary supplementation with rosemary extract and $\alpha$-tocopheryl acetate on lipid oxidation in eggs enriched with $\omega$ 3-fatty acids. Poult Sci. 80(4): $460-467$.

[8]. Botsoglou NA, Florou-Paneri P, Nikolakakis I, Giannenas I, Dotas V, et al., (2005) Effect of dietary saffron (crocus sativus 1.) on the oxidative stability of egg yolk. Br Poult Sci. 46(6): 701-707.

[9]. Florou-Paneri P, Nikolakakis I, Giannenas I, Koidis A, Botsoglou E, et al., (2005) Hen performance and egg quality as affected by dietary oregano essential oil and tocopheryl acetate supplementation. Int J Poult Sci. 4(7): 449-454.

[10]. Krell R (1996) Value-added products from beekeeping. FAO Agricultural Services Bull. No. 124, Food and Agriculture Organization of the United Nations, Rome.

[11]. Delaplane KS (2010) Honey Bees and Beekeeping. Learning for Life. Bulletin. 1045.

[12]. Simone-Finstrom M, Spivak M (2010) Propolis and bee health: the natural history and significance of resin use by honey bees. Apidologie. 41(3): 295311.

[13]. Graikou K, Kapeta S, Aligiannis N, Sotiroudis G, Chondrogianni N, et al., (2011) Chemical analysis of Greek pollen - Antioxidant, antimicrobial and proteasome activation. Chem Cent J. 5: 33.

[14]. Bogdanov S (2013) Pollen: Production, Nutrition and Health: A Review. Bee Product Science, January, 2012.

[15]. https://www.dsm.com/markets/anh/en_US/products/products-feedenzymes/products-feed-proteaseronozymeproact.html, March 2017.

[16]. Seven I, Simsek UG, Gokce Z, Seven PT, Arslan A, Yilmaz O (2014) The effects of royal jelly on performance and fatty acid profiles of different tissues in quail (Coturnix coturnix japonica) reared under high stocking density. Turkish J Veter Ani Sci. 38(3): 271-277.

[17]. Tatlı Seven P, Sur Arslan A, Seven I, Gökçe Z (2016) The effects of dietary bee pollen on lipid peroxidation and fatty acids composition of Japanese quails (Coturnix coturnix japonica) meat under different stocking densities. J Applied Anim Res. 44(1): 487-491.

[18]. AOAC (1995) Official Methods of Analysis. (16th edn) Volume -1, Arlington: Association of Official 252 Analytical Chemists. 4.1-4.17.

[19]. NRC (1994) Nutrient Requirements of Poultry. (9th Rev Edn), Washington, DC: National Academy Press.

[20]. Placer ZA, Cushmann LL, Johnson BC (1966) Estimation of products of lipid peroxidation (malonyl dialdehyde) in biochemical systems. Anal Biochem. 16(2): 359-364.

[21]. Vercellotti JR, ST Angelo AJ , Spanier AM (1992) Lipid Oxidation in Foods, an Overvie. Lipid Oxidation in Food, (Washington, DC, American Chemical Society Press), 112-145.

[22]. Grobas S, Mendez J, Bote BL, De Blas BC, Mateos GG (2002) Effect of vitamin $\mathrm{E}$ and $\mathrm{A}$ supplementation on egg yolk $\alpha$-tocopherol concentration. Poult Sci. 81(3): 376-381.

[23]. Pike OA, Peng IC (1988) Influence of $\mathrm{pH}$ on egg yolk lipid oxidation. J Food Sci. 53(4): 1245-1246.

[24]. Tarladgis BG, Pearson AM, Jun LR (1964) Chemistry of the 2-thiobarbituric acid test for determination of oxidative rancidity in foods. II.-formation of the tba-malonaldehyde complex without acid-heat treatment. J Sci Food Agricul. 15(9): 602-607.

[25]. Raharjo S, Sofos JN (1993) Methodology for measuring malonaldehyde as a product of lipid peroxidation in muscle tissues: A review. Meat Sci. 35(2): 145-169.

[26]. Yalçın S, Yalıın S, Cakın K, Eltan O, Dagasan L (2010) Effects of dietary yeast autolysate (saccharomyces cerevisiae) on performance, egg traits, egg cholesterol content, egg yolk fatty acid composition and humoral immune response of laying hens. J Sci Food Agric. 90(10): 1695-1701.

[27]. Zhang AW, Lee BD, Lee SK, Lee KW, An GH, et al., (2005) Effects of yeast (saccharomyces cerevisiae) cell components on growth performance, meat quality, and ıleal mucosa development of broiler chicks. Poult Sci. 84(7): 1015-1021.

[28]. Tatli Seven P, Yilmaz S, Seven I, Cerci IH, Azman MA, Yilmaz M (2009) Effects of propolis on selected blood indicators and antioxidant enzyme activities in broilers under heat stress. Acta Vet Brno. 78(1): 75-83.

[29]. Ahmad S, Ul-Haq A, Yousaf M, Alam Sabri M, Kamran Z (2012) Response of laying hens to omega- 3 fatty acids for performance and egg quality. Avian Biol Res. 5(1): 1-10.

[30]. Galal A, Abd El-Motaal AM, Ahmed AMH, Zaki TG (2008) Productive performance and immune response of laying hens as affected by dietary propolis supplementation. Int J Poult Sci. 7(3): 272-278.

[31]. Tatli Seven P (2008) The Effects of dietary turkish propolis and vitamin c on performance, digestibility, egg production and egg quality in laying hens under different environmental temperatures. Asian-Australas J Anim Sci. 21(8): 1164-1170. 
[32]. Babaei S, Rahimi S, Torshizi MAK, Tahmasebi G, Miran SNK (2016) Effects of propolis, royal jelly, honey and bee pollen on growth performance and immune system of japanese quails. Vet Res Forum. 7(1): 13.

[33]. Biavatti NW, Bellaver MH, Volpato L, Costa C, Bellaver C (2003) Preliminary studies of alternative feed additives for broilers: alternanthera brasiliana extract, propolis extract and linseed oil. Rev Bras Cienc Avico. 5(2): 147151.

[34]. Denli M, Cankaya S, Silici S, Okan F, Uluocak AN (2005) Effect of dietary addition of turkish propolis on the growth performance, carcass characteristics and serum variables of quail (coturnix coturnix japonica). Asian-Australasian J Anim Sci. 18(6): 848-854.

[35]. Ghisalberti EL (1979) Propolis: A review. Bee World. 60(2): 59-84.

[36]. Buhatel T, Vesa S, Dimitrin A, Moldovan I (1983) contribution to knowledge of the stimulative effect of propolis on piglet and pullets [Romanian]. Bull Univ Agric Sci Vet. Med Cluj Napoca. 37: 45-48.

[37]. Hascik P, Elimam IOE, Garlik J (2012) The Effect of addition bee pollen to feed mixtures on internal fat of broiler ross 308. J MicrobBiotech Food Sci. 2(1): 246-252.

[38]. Bell RR, Thornber EJ, Seet JL, Groves MT, Ho NP, et al., (1983) Composition and protein quality of honey bee-collected pollen of eucalyptus marginata and eucalyptus calophylla. J Nutr. 113(12): 2479-2484.

[39]. Orzaez Villanueva MT, Diaz MA, Bravo SR, Blazquez Abellan G (2002) The importance of bee-collected pollen in the diet: A Study of its composition. Int J Food Sci Nutr. 53(3): 217-224.
[40]. Hascik P, Elimam I, Garlik J, Kacaniova M, Cubon J, et al., (2012) Impact of bee pollen as feed supplements on the body weight of broiler ross 308 . Afr J Biotechnol. 11(89): 15596-15599.

[41]. Mutsauers M, Blitterswijk HV, Leven LV, Kerkvliet J, Waerdt JV (2005) Bee Products: Properties, Processing and Marketing. (1st edn), Wageningen: Digigrafi, 94.

[42]. Abdella EM, Tohamy A, Ahmad RR (2009) Antimutagenic activity of egyptian propolis and bee pollen water extracts against cisplatin-1nduced chromosomal abnormalities in bone marrow cells of mice. Iran J Cancer Prev. 2(4): 175-181.

[43]. Teixeria EW, Message D, Negri G, Salatina A, Stringheta PC (2010) Seasonal variation, chemical composition and antioxidant activity of brazilian propolis samples. Evid Bas Comp Alternat Med. 7(3): 307-315.

[44]. Khalil FA, El-Sheikh NM (2010) The effects of dietary egyptian propolis and bee pollen supplementation against toxicity of sodium fluorid in rats. J Am Sci. 11(6): 310-316.

[45]. Feas X, Vazquez-Tato MP, Estevinho L, Seijas JA, Iglesias A (2012) Organic bee pollen: Botanical origin, nutritional value, bioactive compaunds, antioxidant activity and microbiological quality. Molecules. 17(7): 8359-8377.

[46]. Seven PT, Kelestemur GT, Seven I, Yilmaz S (2012) The Effects of Propolis in Animals Exposed Oxidative Stress. INTECH Open Access Publisher. Oxidative Stress-Environmental Induction and Dietary Antioxidants. Rijeka: 267-288. 